\title{
Antimicrobial and antioxidant screening of curcumin and pyrocatechol in the prevention of biodiesel degradation: oxidative stability
}

\author{
Gustavo A. Santos ${ }^{a}$, Marta M. D. C. Vila ${ }^{a}$, Marco V. Chaud ${ }^{a}$, Willian L. Silva ${ }^{b}$, Adriano G. de Castro ${ }^{b}$, \\ José M. de Oliveira Jr ${ }^{a}$, Matthieu Tubino ${ }^{b}$ and Victor M. Balcão (iD) ${ }^{a, b, c}$ \\ ${ }^{a}$ LaBNUS - Biomaterials and Nanotechnology Laboratory, $\mathbf{i}(\mathbf{b s})^{2}$ - intelligent biosensing and biomolecule stabilization research group, \\ University of Sorocaba, Sorocaba/SP, Brazil; ' Institute of Chemistry, University of Campinas, Campinas/SP, Brazil; ' $\mathrm{C} E B$ - Centre of Biological \\ Engineering, University of Minho, Braga, Portugal
}

\begin{abstract}
Owing to its hygroscopicity biodiesel may accumulate water during storage, which becomes favorable to the growth of microorganisms. In order to control microbial contamination, use of various chemical biocides has been studied. However, the addition of a natural substance simultaneously with antioxidant and microbial growth inhibition could prove advantageous in the prevention of biodiesel oxidation and microbial contamination. Curcumin and pyrocatechol are antioxidant agents, which also exhibit microbial growth inhibition abilities. This research effort aimed at evaluating the addition of curcumin and pyrocatechol to biodiesel produced from various vegetable sources (waste frying oil, soybean oil, cottonseed oil, sesame oil, macaúba almond oil and microalgae oil). The combined addition of $1 \%(\mathrm{w} / \mathrm{w})$ water and curcumin (viz. $0.2 \%(\mathrm{w} / \mathrm{w})$ for biodiesel from spent frying oil, $0.5 \%(\mathrm{w} / \mathrm{w})$ for biodiesel from soybean oil, $0.1 \%(\mathrm{w} / \mathrm{w})$ for biodiesel from cotton seed oil, $0.5 \%(\mathrm{w} / \mathrm{w})$ for biodiesel from sesame seed oil, $0.2 \%(\mathrm{w} / \mathrm{w})$ for biodiesel from macaúba almond oil, and $0.2 \%(\mathrm{w} / \mathrm{w})$ for biodiesel from microalgae oil) were those processing variables that promoted the best fungistatic and antioxidant effects, allowing maintenance of an unfavorable environment for microbial growth in biodiesel inoculated with the ubiquitous filamentous mold Paecilomyces variotii Bainier.
\end{abstract}

ARTICLE HISTORY

Received 9 December 2015 Accepted 26 February 2016

\section{KEYWORDS}

Biodiesel; curcumin and pyrocatechol; microbial growth inhibition; oxidative stability and antimicrobial activity; refractive index

\section{Introduction}

Biodiesel is a fuel derived from renewable sources such as vegetable oils and animal fat, and is a good alternative to fossil oil and diesel oil. Biodiesel has been used by several countries to minimize the effects of greenhouse gas emissions.[1] The $\mathrm{CO}_{2}$ released in the combustion of biodiesel is equal to that captured by plants during photosynthesis and, thus, it does not promote the increase of $\mathrm{CO}_{2}$ in the atmosphere.[2] Biodiesel is composed of a mixture of alkyl esters (methyl, ethyl or propyl) obtained in the transesterification of triglycerides from vegetable oils and animal fats, which is a conventional method for obtaining biodiesel. The triglycerides react with a low molecular weight alcohol, usually methanol or ethanol, resulting in the formation of fatty acid esters and releasing glycerol as a byproduct. The reaction is catalyzed by acids, bases or enzymes. Considering the costs involved, sodium and potassium hydroxides promote satisfactory yields and have been widely used.[3] Microbial contamination of fuels has been reported for more than a century, since it can be spread throughout the storage and distribution systems with serious economical damages.[4,5]
Although the distillation process involved in the production of biodiesel is able to sterilize the biofuel, water, dust and microorganisms can easily enter the system through the storage and transport of the fuel. [4] Furthermore, due to its hygroscopicity water can accumulate during storage of biodiesel, creating a favorable condition for the proliferation of microorganisms.[1] Microbial contamination may gradually degrade the quality of the fuel, favoring the loss of chemical stability.[6,7] Contaminated biodiesel favors the formation of bio-sludge, causing clogging of filters, accelerates the corrosion of various components and features turbidity and unpleasant odor.[1,4] For the prevention or control of biofouling, monitoring and cleaning measures are required, together with the use of chemicals (biocides) capable of inhibiting and controlling microbial growth.[8] Bacteria and fungi are able to proliferate in biofuels, being metabolically more active in interfaces within fuel systems.[5,9] Microorganisms that have been detected in fuel storage systems include fungi, yeasts, and aerobic and anaerobic bacteria.[6,7] A good biocide should be able to act both on the oil and water phases, exhibit a broad

CONTACT Victor M. Balcão victor.balcao@prof.uniso.br @ Universidade de Sorocaba (UNISO), Cidade Universitária Prof. Aldo Vannucchi, Rod. Raposo Tavares km 92.5, CEP 18023-000 Sorocaba/SP, São Paulo, Brazil [Tel.: 0055 (11) 986000 996; Fax: 0055 (15) 21017000 ]. 
spectrum activity, maintain its inhibitory effect in the presence of other substances, not be corrosive to the system, be inexpensive and safe to use, and have a low environmental impact.[1,8,10,11] Another problem that biodiesels feature is susceptibility to oxidation. $[12,13]$ Biodiesels are unstable, particularly when exposed to moisture and atmospheric oxygen, due to their own chemical structure degrading over time. $[1,13]$ Typically, vegetable oils have natural components with antioxidant capacity such as, for example, tocopherols. However, in the (chemical) process of obtaining biodiesels these substances are lost. Thus, addition of chemical substances with antioxidant capacity is a common practice, aiming at maintaining the quality of biodiesel.[13,14] Some natural substances, such as curcumin and pyrocatechol, have antimicrobial and antioxidant activities. In this regard, it may be interesting to add any of these substances to biodiesels so as to minimize both microbial contamination and oxidation. Curcumin [1,7-bis(4-hydroxy-3-methoxyphenyl)-1,6-heptadiene-3,5-dione] is a naturally occurring polyphenol in turmeric (Curcuma longa Linn)[15] possessing several properties, including anti-inflammatory, analgesic, antioxidant[13] and antimicrobial. $[16,17]$ Pyrocatechol (benzene-1,2-diol) is a phenolic compound present in several plant species,[18] presenting antimicrobial[19] and antioxidant[20,21] properties. The mechanisms responsible for microbial toxicity include enzyme inhibition possibly by reaction with hydrogen sulfide groups, or by non-specific reactions with proteins.[22] Considering all the aforementioned facts, the major goal of the research effort entertained herein was to evaluate the use of curcumin and/or pyrocatechol in biodiesels as antimicrobial and antioxidant agents, aiming at determining the lowest concentration that allowed to maintain their antimicrobial and antioxidant activities.[15-21] These natural substances may exert their toxicity to microbial cells possibly by mechanisms involving intracytoplasmatic enzyme inhibition.[22] Hence, in the research effort entertained herein, the long-term effects of the addition of curcumin to several different biodiesels was studied, in terms of the maintenance of both their oxidative stability and harsh environment for microbial growth.

\section{Materials and methods}

\section{Materials}

\section{Chemicals}

The reagents utilized in this research work were all of analytical grade or better, and were used without any type of additional purification. Tap water was purified in a Milli-Q Elga Purelab system (Molsheim, France) to a final conductivity of ca. $18.2 \mathrm{M} \Omega \cdot \mathrm{cm}^{-1}$. Curcumin was purchased from Merck (Hohenbrunn, Germany) and pyrocatechol was acquired from Fluka (Buchs SG, Switzerland). For the microbiological assays, nutritive medium Sabouraud Dextrose Agar was purchased from Promidol Biotecnologia (Belo Horizonte MG, Brazil) and disposable sterile Petri plates were acquired from J. Prolab (São José dos Pinhais PR, Brazil). The microorganism utilized in all biodiesel inoculation experiments was the filamentous mold Paecilomyces variotii Bainier (code CMMAI 0543), acquired from the Brazilian Collection of Environment and Industry Microorganisms (CBMAl) of the Multidisciplinary Center for Chemical, Biological and Agricultural Research at the Campinas State University (CPQBA/UNICAMP, Campinas SP, Brazil). To synthesize the various biodiesels utilized in this research effort, refined soybean oil was acquired at the local commerce in the city of Campinas (Campinas SP, Brazil), spent frying oil was collected through the Selective Waste Collection Program of the Environment Division of the State University of Campinas, cotton seed oil and microalgae oil were a kind gift from EXTRAE/FEA/UNICAMP, sesame seed oil was a kind gift from Sésamo Real Indústria e Comércio de Produtos Alimentícios Ltda. (Valinhos SP, Brazil), and macaúba almond oil was acquired from Community Association of Small Farmers of Dantas Creek and Montes Claros adjacencies (Minas Gerais MG, Brazil). The reagents utilized to prepare the different biodiesels were absolute methanol, purchased from Synth (Diadema SP, Brazil), and sodium methoxide solution at $30 \%(\mathrm{w} / \mathrm{w})$ in methanol, purchased from Vetec (Rio de Janeiro RJ, Brazil), used as catalyst for the transesterification reactions.

\section{Analytical equipment}

The lipid oxidation induction times of the several biodiesels studied were determined in a Biodiesel Rancimat from Metrohm AG (model 873, Herisau, Switzerland). All refractive index (RI) measurements were carried out in a Digital Refractometer from Mettler-Toledo (model Refracto 30GS, Greifensee, Switzerland).

\section{Experimental procedures}

\section{Preparation of biodiesel}

The syntheses of biodiesels were carried out in three sequential steps. In the first step, $16 \%(w / w)$ methanol and $0.58 \%(\mathrm{w} / \mathrm{w})$ of methanolic solution of sodium methoxide (at 30\%, w/w) were added, relative to the initial mass of oil. This mixture was maintained at $60^{\circ} \mathrm{C}$ with reflux, under mechanical stirring at $900 \mathrm{rpm}$, for $1 \mathrm{~h}$. Subsequently, the reaction mixture was transferred into a separatory funnel for decantation, separation and removal of glycerol. After removal of the glycerol, the second reaction step took place with the addition of an extra $4 \%(\mathrm{w} / \mathrm{w})$ of ethanol and $0.14 \%(\mathrm{w} / \mathrm{w})$ of methanolic solution of sodium methoxide (at $30 \%, \mathrm{w} /$ 
w), percentages relative to the initial mass of oil, under the same experimental conditions of stirring, temperature, time and reflux. In the third stage, the biodiesel produced was washed with $5 \times 50 \mathrm{~mL}$ of water at $60^{\circ} \mathrm{C}$, dried in an oven set at $100^{\circ} \mathrm{C}$ for $1 \mathrm{~h}$ and purified on a column packed with ion exchange resin (Amberlite BD10 DRY, from Dow Chemical Brazil, São Paulo, SP, Brazil), employing ca. $180 \mathrm{~g}$ of resin per liter of biodiesel and a biodiesel flow rate of $4 \mathrm{~mL} \mathrm{~min}^{-1}$.

\section{Preparation of biodiesel samples with curcumin and pyrocatechol for antimicrobial screening}

Biodiesel samples were added with curcumin or pyrocatechol at variable weight percentages of $0 \%, 0.1 \%$, $0.2 \%, 0.5 \%, 1.0 \%$, and $1.5 \%(\mathrm{w} / \mathrm{w})$. The presence of water was also evaluated, with addition of $1 \%$ water $(w / w)$ to biodiesel samples containing added curcumin or pyrocatechol. Figure 1 presents the experimental design utilized. All biodiesel samples added with curcumin or pyrocatechol, in the absence or presence of $1 \%$ $(\mathrm{w} / \mathrm{w})$ added water, were stored in amber glass bottles and kept at $4{ }^{\circ} \mathrm{C}$ until use.

\section{Evaluation of the potential microbial growth inhibition properties of curcumin and pyrocatechol in biodiesel}

For determination of the minimum concentration of curcumin and pyrocatechol able to produce fungistatic effects in the biodiesels studied, the filamentous mold Paecilomyces variotii Bainier was utilized. The microorganism (in the form of a lyophilized pellet) was reactivated by the addition of ca. $5 \mathrm{~mL}$ of sterile saline solution (at $0.9 \% \mathrm{NaCl}(\mathrm{w} / \mathrm{w})$ in ultrapure water). After complete rehydration of the pellet, the solution was gently shaken and poured into Petri plates containing solid Sabouraud Dextrose Agar, and the plates incubated for $48 \mathrm{~h}$ at $25^{\circ} \mathrm{C}$ in an incubation chamber from QUIMIS (model Q-316-14, Diadema, SP, Brazil). After incubation, a colony forming unit (CFU) was selected and withdrawn using a flamed metallic loop, and

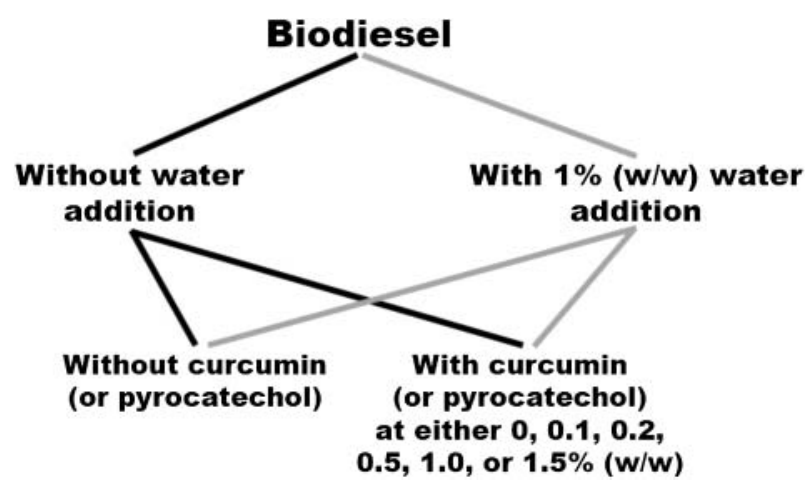

Figure 1. Experimental design for assessing the effect of curcumin or pyrocatechol as antimicrobial and/or antioxidant agents in biodiesel samples, in the presence or absence of added water. suspended in sterile liquid nutritive broth, after which the tube was incubated for $48 \mathrm{~h}$ at $25^{\circ} \mathrm{C}$. After this time period, and following homogenization of the inoculum, a sterile swab was introduced and submerged in the liquid culture suspension, the excess solution was withdrawn via gentle compression against the tube walls, and the surface of the Sabouraud Dextrose Agar in Petri plates was inoculated in the form of striae in three directions, in each (previously marked) quadrant. Immediately after inoculation, 20 $\mu L$ of each biodiesel sample with a given weight percentage of curcumin or pyrocatechol (with and without added water) were poured in the centre of each quadrant in the form of a simple (tiny) drop, using sterile tips and a Gilson automatic pipette. For each biodiesel, samples added with either curcumin or pyrocatechol were poured into four Petri plates with solid Sabouraud Dextrose Agar using the following sequence: Petri plate \#1: top right quadrant, $0 \%(\mathrm{w} / \mathrm{w})$ curcumin; top left quadrant, $0.1 \%(\mathrm{w} / \mathrm{w})$ curcumin; bottom right quadrant, $0.2 \%(\mathrm{w} / \mathrm{w})$ curcumin; bottom left quadrant, $0.5 \%(\mathrm{w} / \mathrm{w})$ curcumin; Petri plate \#2: top right quadrant, $0 \%(\mathrm{w} / \mathrm{w})$ curcumin; top left quadrant, $0.5 \%(\mathrm{w} / \mathrm{w})$ curcumin; bottom right quadrant, $1.0 \%(\mathrm{w} / \mathrm{w})$ curcumin; bottom left quadrant, $1.5 \%(\mathrm{w} / \mathrm{w})$ curcumin; Petri plate \#3: top right quadrant, $0 \%(\mathrm{w} / \mathrm{w})$ pyrocatechol; top left quadrant, $0.1 \%(\mathrm{w} / \mathrm{w})$ pyrocatechol; bottom right quadrant, $0.2 \%(\mathrm{w} / \mathrm{w})$ pyrocatechol; bottom left quadrant, $0.5 \%(\mathrm{w} / \mathrm{w})$ pyrocatechol; Petri plate \#4: top right quadrant, $0 \%(\mathrm{w} / \mathrm{w})$ pyrocatechol; top left quadrant, $0.5 \%$ $(\mathrm{w} / \mathrm{w})$ pyrocatechol; bottom right quadrant, 1.0\% (w/w) pyrocatechol; bottom left quadrant, $1.5 \%(\mathrm{w} / \mathrm{w})$ pyrocatechol. All Petri plates were incubated at $25^{\circ} \mathrm{C}$ for 48 $h$, after which they were visually inspected for the presence of growth inhibition halos. Measurement of halo diameters was carried out using a caliper rule and reflected light to illuminate the Petri plates (in inverted position) placed on a black and opaque background. All procedures were carried out under aseptic conditions in a laminar flow chamber from Trox Technik (model FLV-II, Sorocaba, SP, Brazil). The Petri plates containing solid culture medium were prepared according to procedures from the manufacturers and following instructions from CLSI.[23]

\section{Evaluation of the potential antioxidant activity of curcumin and pyrocatechol in biodiesel and of the oxidative stability of biodiesels added with curcumin The induction period that expresses the oxidative sta- bility was determined by following the procedure of the norm EN 14112,[24] in a Biodiesel Rancimat from Metrohm AG (model 873, Herisau, Switzerland). All measurements were performed in triplicate. This method consisted in using $3 \mathrm{~g}$ of biodiesel which were heated up to $110^{\circ} \mathrm{C}$, and maintained at this tempera- ture, under a constant air flow of $10{\mathrm{~L} \bullet \mathrm{h}^{-1}}^{\text {. }}$}




\section{Preparation of biodiesel samples with curcumin for antimicrobial and oxidative stability screening}

Biodiesels were added with curcumin at variable (previously optimized) weight percentages of $0.1 \%(\mathrm{w} / \mathrm{w})$ (biodiesel from cotton seed oil), $0.2 \%(\mathrm{w} / \mathrm{w})$ (biodiesel from spent frying oil), and $0.5 \%(\mathrm{w} / \mathrm{w}$ ) (biodiesels from sesame seed oil and soybean oil). All four biodiesels added with curcumin were also added with $1 \%$ water $(\mathrm{w} / \mathrm{w})$ and further inoculated with a sterile Drigalski loop full with mycelium from Paecilomyces variotii Bainier previously grown in solid nutritive medium Sabouraud Dextrose Agar in a Petri dish. All biodiesels were subsequently stored in amber glass bottles and stored for six months at $25^{\circ} \mathrm{C}$. At pre-determined time intervals $(0,30,60,90,120,150$ and 180 days), aliquots of all biodiesels were withdrawn and analyzed for RI (always at $25^{\circ} \mathrm{C}$ ), lipid oxidation induction times and presence of viable cells of Paecilomyces variotii Bainier. Plain biodiesel samples were also evaluated for $\mathrm{RI}$ and lipid oxidation induction time.

\section{Evaluation of the antimicrobial properties of biodiesels added with curcumin}

All biodiesels prepared according to the procedure described in section "Preparation of biodiesel". were screened for the presence of viable cells of Paecilomyces variotii Bainier. At pre-determined time intervals, $100 \mu \mathrm{L}$ samples of each biodiesel added with curcumin and water and further inoculated with the filamentous mold were withdrawn and poured and duly spread into Petri plates containing solid Sabouraud Dextrose Agar, using a sterile Drigalski loop, with the plates being incubated for $48 \mathrm{~h}$ at $25^{\circ} \mathrm{C}$ in an incubation chamber from QUIMIS (model Q-316-14, Diadema, SP, Brazil). After the incubation period, all Petri plates were observed for the presence of fungal growth and any colony forming units (CFUs) duly counted. All procedures were carried out under aseptic conditions in a laminar flow chamber from Trox Technik (model FLV-II, Sorocaba, SP, Brazil). The Petri plates containing solid culture medium were prepared according to procedures from the manufacturers and following instructions from CLSI.[23]

\section{Results and discussion}

Undoubtedly, one of the biggest problems with biodiesel is related to its stability, and the most significant factors for its degradation include exposure to air and/ or light, high temperatures and even to the presence of metals that can eventually act as catalysts in the process of its oxidation. The presence of microorganisms has also been reported as a factor that promotes biodiesel degradation, with a significant drop in its quality. $[4,5,9,11,25]$ Hence, to minimize this problem, the research work entertained herein aimed at studying the effects of the addition to biodiesel of natural substances with reported antimicrobial and antioxidant properties. Thus, the research work undertaken was divided into two major parts, the first of which aimed at determining the lowest concentrations of pyrocatechol or curcumin exercising inhibition of microbial growth and/or antioxidant activities in biodiesels produced from oils from different plant origins. The second part aimed at following over a relatively long storage time, the effect of such natural additives in the maintenance of the properties and quality of biodiesel. All newly prepared biodiesels were screened for microbial loads, but all produced negative results, which is in clear agreement with the processing conditions leading to the production of this biofuel.[4] Saponification is an important side-reaction in this type of system, influencing both catalyst and soaps distribution between the biodiesel and the glycerine phases. A very important fraction of the hydroxides are consumed by the saponification reaction, thus decreasing the final acyl-glycerides conversion. By carrying out the reaction in two steps, improvement was obtained regarding the consumption of catalyst and soap formation, in part promoted by the water formed by free fatty acid neutralization. Hence, when using crude oils (including wasted frying oil), the two-step transesterification process allowed minimization of soap formation and its solubility in the biodiesel phase.

\section{Evaluation of the potential microbial growth inhibition activity of curcumin and pyrocatechol in biodiesel}

To test the potential of the addition of natural substances such as curcumin or pyrocatechol to biodiesel, in preventing and/or controlling microbial (fungal) contamination and oxidation, it was decided to inoculate all newly prepared biodiesels with an ubiquitous microorganism able to withstand the prevailing conditions in such a medium and at the same time able to thrive in them. The microorganism chosen was the filamentous mold Paecilomyces variotii Bainier, due to the fact that it is a common contaminating agent in diesel fuels[5] and also because of the availability to acquire a strain of guaranteed origin. In a first stage, we were interested in studying a single microorganism and not a cocktail of different organisms. The presence of water as a facilitator or inhibitor of the activity of the added natural agent(s) was also evaluated and, for this, all newly prepared biodiesels were added with $1 \%(\mathrm{w} / \mathrm{w})$ ultrapure water, aiming at simulating biodiesel hydration during storage up to 20 times the maximum legally permitted water level $(500 \mathrm{ppm})$ in Brazil (ANP $42 /[26])$. In real conditions of storage, biodiesel can suffer accidental contamination with water from infiltrations (e.g. rain, washing of the refueling points, microcracks in the storage tanks) and, in this sense, it 


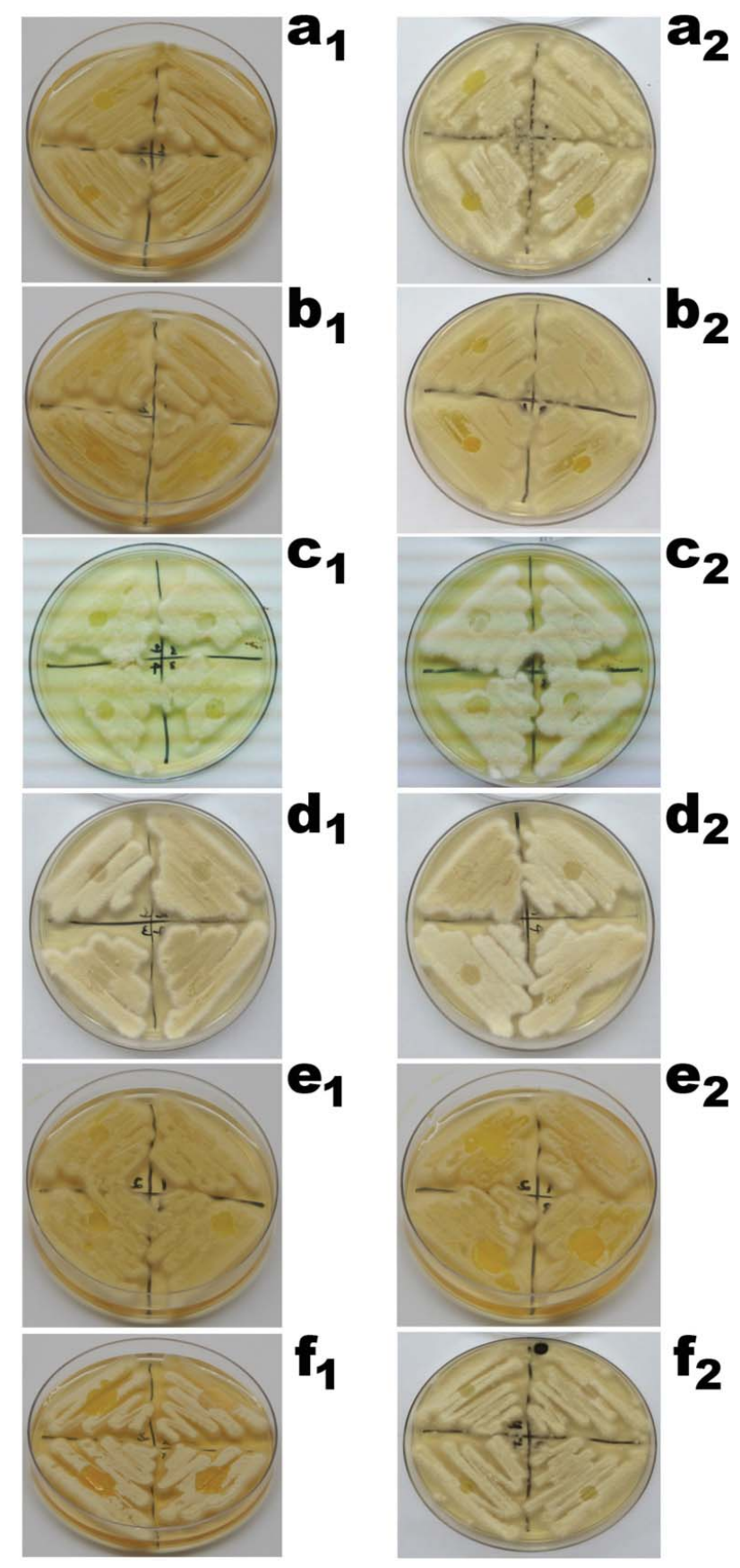

Figure 2. Results obtained for the fungal inhibition ability of biodiesel samples added with variable amounts of curcumin. $\mathrm{a}_{1}$ : biodiesel from spent frying oil without added water, top right quadrant, $0 \%(\mathrm{w} / \mathrm{w})$ curcumin; top left quadrant, $0.1 \%$ (w/w) curcumin; bottom right quadrant, $0.2 \%(\mathrm{w} / \mathrm{w})$ curcumin; bottom left quadrant, $0.5 \%(\mathrm{w} / \mathrm{w})$ curcumin; $\mathrm{a}_{2}$ : biodiesel from spent frying oil with $1 \%(\mathrm{w} / \mathrm{w})$ added water, top right quadrant, $0 \%(\mathrm{w} / \mathrm{w})$ curcumin; top left quadrant, $0.1 \%(\mathrm{w} / \mathrm{w})$ curcumin; bottom right quadrant, $0.2 \%(\mathrm{w} / \mathrm{w})$ curcumin; bottom left quadrant, $0.5 \%(\mathrm{w} / \mathrm{w})$ curcumin; $\mathbf{b}_{1}$ : biodiesel from soybean oil without added water, top right quadrant, $0 \%(\mathrm{w} / \mathrm{w})$ curcumin; top left quadrant, $0.1 \%(\mathrm{w} / \mathrm{w})$ curcumin; bottom right quadrant, $0.2 \%(\mathrm{w} / \mathrm{w})$ curcumin; bottom left quadrant, $0.5 \%(\mathrm{w} / \mathrm{w})$ curcumin; $\mathbf{b}_{2}$ : biodiesel from soybean oil with $1 \%(\mathrm{w} / \mathrm{w})$ added water, top right quadrant, $0 \%$ (w/w) curcumin; top left quadrant, $0.5 \%(\mathrm{w} / \mathrm{w})$ curcumin; bottom right quadrant, $1.0 \%(\mathrm{w} / \mathrm{w})$ curcumin; bottom left quadrant, $1.5 \%$ (w/w) curcumin; $\mathrm{c}_{1}$ : biodiesel from cotton seed oil without added water, top right quadrant, $0 \%(\mathrm{w} / \mathrm{w})$ curcumin; top left quadrant, $0.5 \%$ (w/w) curcumin; bottom right quadrant, $1.0 \%(\mathrm{w} / \mathrm{w})$ curcumin; bottom left quadrant, $1.5 \%(\mathrm{w} / \mathrm{w})$ curcumin; $\mathrm{c}_{2}$ : biodiesel from cotton seed oil with $1 \%(\mathrm{w} / \mathrm{w})$ added water, top right quadrant, $0 \%(\mathrm{w} / \mathrm{w})$ curcumin; top left quadrant, $0.1 \%(\mathrm{w} / \mathrm{w})$ curcumin; bottom right quadrant, $0.2 \%(\mathrm{w} / \mathrm{w})$ curcumin; bottom left quadrant, $0.5 \%(\mathrm{w} / \mathrm{w})$ curcumin; $\mathrm{d}_{1}$ : biodiesel from sesame seed oil without added water, top right quadrant, $0 \%(\mathrm{w} / \mathrm{w})$ curcumin; top left quadrant, $0.5 \%(\mathrm{w} / \mathrm{w})$ curcumin; bottom right quadrant, $1.0 \%$ (w/w) curcumin; bottom left quadrant, $1.5 \%(\mathrm{w} / \mathrm{w})$ curcumin; $\mathbf{d}_{2}$ : biodiesel from sesame seed oil with $1 \%(\mathrm{w} / \mathrm{w})$ added water, top right quadrant, $0 \%(\mathrm{w} / \mathrm{w})$ curcumin; top left quadrant, $0.5 \%(\mathrm{w} / \mathrm{w})$ curcumin; bottom right quadrant, $1.0 \%(\mathrm{w} / \mathrm{w})$ curcumin; bottom left quadrant, $1.5 \%(\mathrm{w} / \mathrm{w})$ curcumin; $\mathbf{e}_{1}$ : biodiesel from macaúba palm oil without added water, top right quadrant, $0 \%$ (w/w) curcumin; top left quadrant, $0.5 \%(\mathrm{w} / \mathrm{w})$ curcumin; bottom right quadrant, $1.0 \%(\mathrm{w} / \mathrm{w})$ curcumin; bottom left quadrant, $1.5 \%$ (w/w) curcumin; $\mathbf{e}_{2}$ : biodiesel from macaúba palm oil with $1 \%(\mathrm{w} / \mathrm{w})$ added water, top right quadrant, $0 \%(\mathrm{w} / \mathrm{w})$ curcumin; top left quadrant, $0.1 \%$ (w/ w) curcumin; bottom right quadrant, $0.2 \%(w / w)$ curcumin; bottom left quadrant, $0.5 \%(w / w)$ curcumin; $f_{1}$ : biodiesel from microalgae oil without added water, top right quadrant, $0 \%(\mathrm{w} / \mathrm{w})$ curcumin; top left quadrant, $0.1 \%(\mathrm{w} / \mathrm{w})$ curcumin; bottom right quadrant, $0.2 \%(\mathrm{w} / \mathrm{w})$ curcumin; bottom left quadrant, $0.5 \%(\mathrm{w} / \mathrm{w})$ curcumin; $\mathbf{f}_{2}$ : biodiesel from microalgae oil with $1 \%(\mathrm{w} / \mathrm{w})$ added water, top right quadrant, $0 \%(\mathrm{w} / \mathrm{w})$ curcumin; top left quadrant, $0.1 \%(\mathrm{w} / \mathrm{w})$ curcumin; bottom right quadrant, $0.2 \%(\mathrm{w} / \mathrm{w})$ curcumin; bottom left quadrant, $0.5 \%(\mathrm{w} / \mathrm{w})$ curcumin. 
was considered important to define the microbial growth inhibition properties the closest as possible to the real conditions. The results of the microbial growth inhibition trials obtained for all biodiesel samples added with either curcumin or pyrocatechol, in the presence of $1 \%(\mathrm{w} / \mathrm{w})$ added water or in its absence, are displayed in Figure 2 for curcumin and in Figure 3 for pyrocatechol, in the form of inhibition halos.

As can be seen from inspection of Figures 2 and 3, when no curcumin or pyrocatechol were added, the mycelium grew and entangled above the biodiesel droplet, producing a 'fake' inhibition zone. To allow a better comparison of the halos produced in the different situations, for every biodiesel tested the halos produced were normalized by the dimension of the inhibition zone produced solely by biodiesel (i.e., without any addition of either curcumin or pyrocatechol). A close inspection of the results depicted in Table 1, in the form of normalized growth inhibition halo diameters, allows to draw as a general conclusion that the combined addition of $1 \%(\mathrm{w} / \mathrm{w})$ water and a low mass concentration of curcumin (viz. $0.2 \%(\mathrm{w} / \mathrm{w})$ for biodiesel from spent frying oil, $0.5 \%(\mathrm{w} / \mathrm{w})$ for biodiesel from soybean oil, $0.1 \%(\mathrm{w} / \mathrm{w})$ for biodiesel from cotton seed oil, $0.5 \%(\mathrm{w} / \mathrm{w})$ for biodiesel from sesame seed oil, $0.2 \%$ $(w / w)$ for biodiesel from macaúba almond oil, and $0.2 \%(\mathrm{w} / \mathrm{w})$ for biodiesel from microalgae oil) were those processing variables that promoted the best inhibition of fungal growth (see Table 1).

Due to legal restrictions, the amount of any additive added to biodiesel must be kept to a minimum. For all biodiesels produced from different vegetable sources and added with $1 \%(\mathrm{w} / \mathrm{w})$ water, curcumin and pyrocatechol produced quite similar results in preventing microbial growth. However, due to the ease of curcumin availability, compared to pyrocatechol, the former was chosen for further work. Additionally, the halos of microbial growth inhibition produced by curcumin were in general larger than those promoted by pyrocatechol (see Table 1).

\section{Evaluation of the potential antioxidant activity of curcumin and pyrocatechol in biodiesel, and of the oxidative stability of biodiesels added with curcumin}

The potential antioxidant effect of curcumin in all biodiesels added with $1 \%(\mathrm{w} / \mathrm{w})$ ultrapure water was also evaluated. As can be seen in Table 2, lipid oxidation induction times (average of three determinations and associated standard deviations) of biodiesels added with (minimum) variable amounts of curcumin and $1 \%$ $(w / w)$ water (see section "Evaluation of the potential microbial growth inhibition activity of curcumin and pyrocatechol in biodiesel") suffered a generalized increase when compared with their pure counterparts (see Table 2). Except for the biodiesel produced from soybean oil, which suffered a $16 \%$ reduction in the lipid oxidation induction time, meaning that this biodiesel was more prone to oxidation after the combined addition of water and curcumin, all other biodiesels proved to be more resistant to oxidation, with large increases in their lipid oxidation induction times (see Table 2). Additionally, plain biodiesel produced from macaúba almond oil proved to be very resistant to oxidation, exhibiting a lipid oxidation induction timeframe of more than $60 \mathrm{~h}$, making irrelevant the addition of any antioxidant. Even more, the addition of curcumin to this biodiesel catapulted the induction of lipid oxidation to more than $140 \mathrm{~h}$. Thus, this biodiesel was discontinued from further studies. The same happened to biodiesel produced from microalgae oil, due to the difficulty in obtaining this still experimental biodiesel in large amounts. But for the remaining biodiesels (see Table 2), and except for the biodiesel produced from soybean oil, lipid oxidation induction times suffered large increases, from ca. $28 \%$ in the case of biodiesel produced from sesame seed oil to ca. $41 \%$ in the case of biodiesel produced from spent frying oil. In our opinion, these results demonstrate the potential of the addition of curcumin to biodiesels in preventing both lipid oxidation and fungal growth. Although the results presented in the present research effort shed some light onto the use of curcumin as a potential additive to biodiesel, an in-depth study will be required in order to definitely establish curcumin as a suitable additive to biodiesel, namely by using the methodology described by the Clinical and Laboratory Standards Institute (formerly, the NCCLS),[27] and also by inoculating the biodiesels with different microorganisms, either isolated or in consortium. The definite validation of curcumin as a suitable additive to biodiesel would also be accomplished through the use of the protocol described in ASTM Standard E1259-10.[28]

Lipid oxidation induction times of the several biodiesels studied, before and after addition of curcumin and $1 \%(\mathrm{w} / \mathrm{w})$ water and throughout a storage timeframe of six months, in the presence of water, can be found in Table 3 and Figure 4 as average values of three replicates and associated standard deviations.

As can be seen in Table 3 and Figure 4, lipid oxidation induction times (average of three determinations and associated standard deviations) of biodiesels added with curcumin in the presence of $1 \%(\mathrm{w} / \mathrm{w})$ water suffered a generalized increase immediately after addition of curcumin, except in the case of biodiesel produced from soybean oil, which suffered a $16 \%$ reduction in the lipid oxidation induction time, meaning that this biodiesel was more prone to oxidation after the combined addition of water and curcumin. However, after the first month of storage, the biodiesel produced from soybean oil was relatively stable from the oxidation point of view. Except for biodiesel 


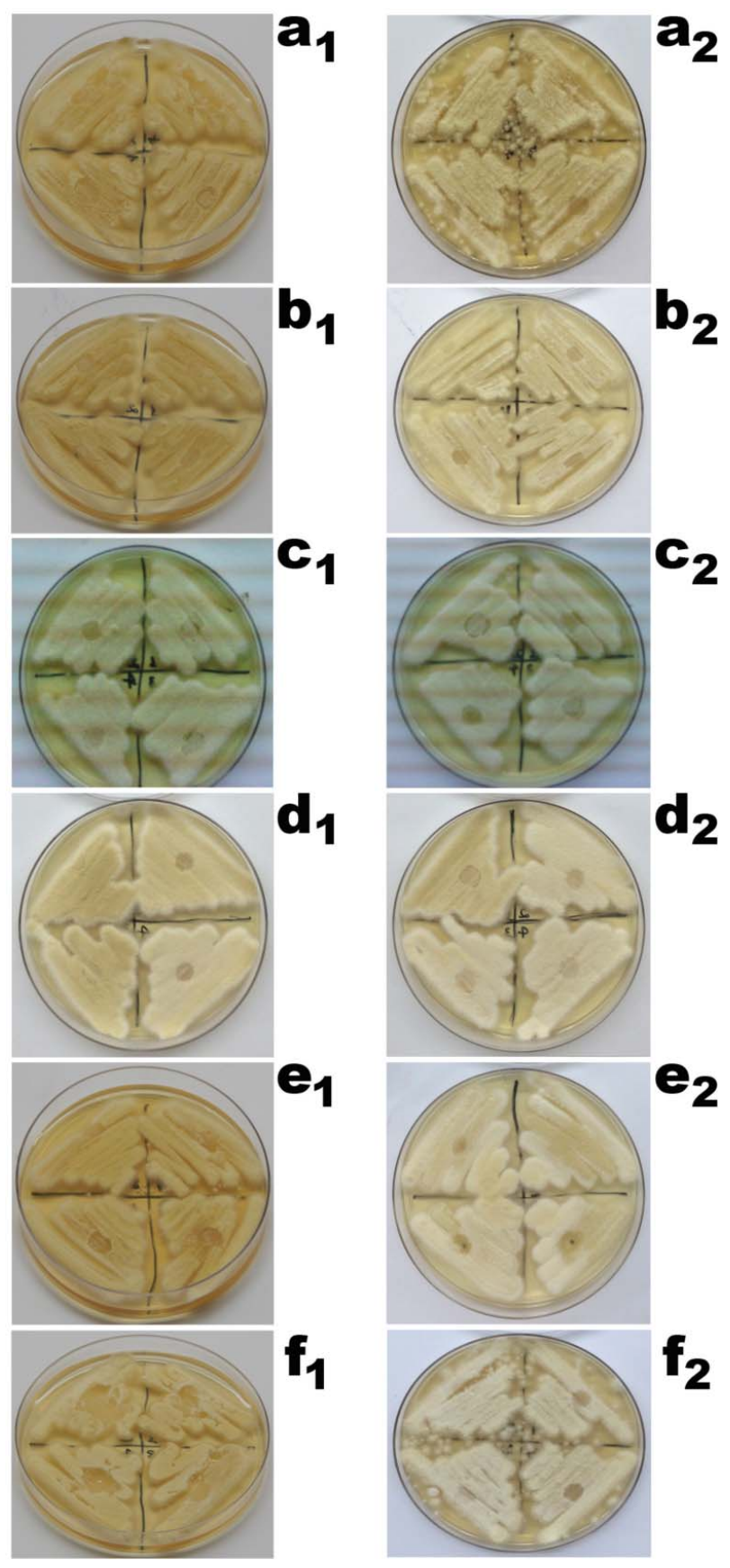

Figure 3. Results obtained for the fungal inhibition ability of biodiesel samples added with variable amounts of pyrocatechol. $\mathrm{a}_{1}$ : biodiesel from spent frying oil without added water, top right quadrant, $0 \%(\mathrm{w} / \mathrm{w})$ pyrocatechol; top left quadrant, $0.5 \%$ (w/w) pyrocatechol; bottom right quadrant, $1.0 \%(\mathrm{w} / \mathrm{w})$ pyrocatechol; bottom left quadrant, $1.5 \%(\mathrm{w} / \mathrm{w})$ pyrocatechol; $\mathrm{a}_{2}$ : biodiesel from spent frying oil with $1 \%(\mathrm{w} / \mathrm{w})$ added water, top right quadrant, $0 \%(\mathrm{w} / \mathrm{w})$ pyrocatechol; top left quadrant, $0.1 \%(\mathrm{w} / \mathrm{w})$ pyrocatechol; bottom right quadrant, $0.2 \%(\mathrm{w} / \mathrm{w})$ pyrocatechol; bottom left quadrant, $0.5 \%(\mathrm{w} / \mathrm{w})$ pyrocatechol; $\mathbf{b}_{1}$ : biodiesel from soybean oil without added water, top right quadrant, $0 \%(\mathrm{w} / \mathrm{w})$ pyrocatechol; top left quadrant, $0.1 \%(\mathrm{w} / \mathrm{w})$ pyrocatechol; bottom right quadrant, $0.2 \%(\mathrm{w} / \mathrm{w})$ pyrocatechol; bottom left quadrant, $0.5 \%(\mathrm{w} / \mathrm{w})$ pyrocatechol; $\mathbf{b}_{2}$ : biodiesel from soybean oil with $1 \%(\mathrm{w} / \mathrm{w})$ added water, top right quadrant, $0 \%(\mathrm{w} / \mathrm{w})$ pyrocatechol; top left quadrant, $0.1 \%(\mathrm{w} / \mathrm{w})$ pyrocatechol; bottom right quadrant, $0.2 \%$ $(\mathrm{w} / \mathrm{w})$ pyrocatechol; bottom left quadrant, $0.5 \%(\mathrm{w} / \mathrm{w})$ pyrocatechol; $\mathrm{c}_{1}$ : biodiesel from cotton seed oil without added water, top right quadrant, $0 \%(\mathrm{w} / \mathrm{w})$ pyrocatechol; top left quadrant, $0.1 \%(\mathrm{w} / \mathrm{w})$ pyrocatechol; bottom right quadrant, $0.2 \%(\mathrm{w} / \mathrm{w})$ pyrocatechol; bottom left quadrant, $0.5 \%(\mathrm{w} / \mathrm{w})$ pyrocatechol; $\mathrm{c}_{2}$ : biodiesel from cotton seed oil with $1 \%(\mathrm{w} / \mathrm{w})$ added water, top right quadrant, $0 \%(\mathrm{w} / \mathrm{w})$ pyrocatechol; top left quadrant, $0.1 \%(\mathrm{w} / \mathrm{w})$ pyrocatechol; bottom right quadrant, $0.2 \%(\mathrm{w} / \mathrm{w})$ pyrocatechol; bottom left quadrant, $0.5 \%(\mathrm{w} / \mathrm{w})$ pyrocatechol; $\mathbf{d}_{1}$ : biodiesel from sesame seed oil without added water, top right quadrant, $0 \%(\mathrm{w} / \mathrm{w}$ ) pyrocatechol; top left quadrant, $0.1 \%(\mathrm{w} / \mathrm{w})$ pyrocatechol; bottom right quadrant, $0.2 \%(\mathrm{w} / \mathrm{w})$ pyrocatechol; bottom left quadrant, $0.5 \%(\mathrm{w} / \mathrm{w})$ pyrocatechol; $\mathbf{d}_{2}$ : biodiesel from sesame seed oil with $1 \%(\mathrm{w} / \mathrm{w})$ added water, top right quadrant, $0 \%(\mathrm{w} / \mathrm{w})$ pyrocatechol; top left quadrant, $0.1 \%(\mathrm{w} / \mathrm{w})$ pyrocatechol; bottom right quadrant, $0.2 \%(\mathrm{w} / \mathrm{w})$ pyrocatechol; bottom left quadrant, $0.5 \%$ $(\mathrm{w} / \mathrm{w})$ pyrocatechol; $\mathbf{e}_{1}$ : biodiesel from macaúba palm oil without added water, top right quadrant, $0 \%(\mathrm{w} / \mathrm{w})$ pyrocatechol; top left quadrant, $0.1 \%(\mathrm{w} / \mathrm{w})$ pyrocatechol; bottom right quadrant, $0.2 \%(\mathrm{w} / \mathrm{w})$ pyrocatechol; bottom left quadrant, $0.5 \%$ (w/w) pyrocatechol; $\mathbf{e}_{2}$ : biodiesel from macaúba palm oil with $1 \%(\mathrm{w} / \mathrm{w})$ added water, top right quadrant, $0 \%(\mathrm{w} / \mathrm{w})$ pyrocatechol; top left quadrant, $0.5 \%(\mathrm{w} / \mathrm{w})$ pyrocatechol; bottom right quadrant, $1.0 \%(\mathrm{w} / \mathrm{w})$ pyrocatechol; bottom left quadrant, $1.5 \%(\mathrm{w} / \mathrm{w})$ pyrocatechol; $\mathrm{f}_{1}$ : biodiesel from microalgae oil without added water, top right quadrant, $0 \%(\mathrm{w} / \mathrm{w})$ pyrocatechol; top left quadrant, $0.1 \%(\mathrm{w} / \mathrm{w})$ pyrocatechol; bottom right quadrant, $0.2 \%(\mathrm{w} / \mathrm{w})$ pyrocatechol; bottom left quadrant, $0.5 \%(\mathrm{w} / \mathrm{w})$ pyrocatechol; $\mathrm{f}_{2}$ : biodiesel from microalgae oil with $1 \%(\mathrm{w} / \mathrm{w})$ added water, top right quadrant, $0 \%(\mathrm{w} / \mathrm{w})$ pyrocatechol; top left quadrant, $0.1 \%(\mathrm{w} / \mathrm{w})$ pyrocatechol; bottom right quadrant, $0.2 \%(\mathrm{w} / \mathrm{w})$ pyrocatechol; bottom left quadrant, $0.5 \%(\mathrm{w} / \mathrm{w})$ pyrocatechol. 
Table 1. Normalized growth inhibition halos produced using the filamentous fungi Paecilomyces variotii Bainier and biodiesels from different vegetable origins added with variable weight percentages of either curcumin or pyrocatechol.

\begin{tabular}{|c|c|c|c|c|c|}
\hline \multirow[b]{2}{*}{$\begin{array}{l}\text { BIODIESEL } \\
\text { ORIGIN }\end{array}$} & \multirow[b]{2}{*}{$\begin{array}{l}\text { Additive added to } \\
\text { biodiesel }(\%, w / w)\end{array}$} & \multicolumn{4}{|c|}{ Normalized inhibition halos produced } \\
\hline & & $\begin{array}{l}\text { With curcumin/ } \\
\text { Without water }\end{array}$ & $\begin{array}{l}\text { With curcumin/ } \\
\text { With water }\end{array}$ & $\begin{array}{l}\text { With pyrocatechol/ } \\
\text { Without water }\end{array}$ & $\begin{array}{c}\text { With pyrocatechol/ } \\
\text { With water }\end{array}$ \\
\hline \multirow[t]{6}{*}{ Spent frying oil } & 0 & $8 / 8=1.000$ & $7 / 7=1.000$ & $10 / 10=1.000$ & $10 / 10=1.000$ \\
\hline & 0.1 & $10 / 8=1.250$ & $10 / 7=1.429$ & $10 / 10=1.000$ & $10 / 10=1.000$ \\
\hline & 0.2 & $7 / 8=0.875$ & $10 / 7=1.429$ & $7 / 10=0.700$ & $8 / 10=0.800$ \\
\hline & 0.5 & $8 / 8=1.000$ & $8 / 7=1.143$ & $8 / 10=0.800$ & $10 / 10=1.000$ \\
\hline & 1.0 & $8 / 8=1.000$ & $6 / 7=0.857$ & $12 / 10=1.200$ & $9 / 10=0.900$ \\
\hline & 1.5 & $8 / 8=1.000$ & $7 / 7=1.000$ & $12 / 10=1.200$ & $5 / 10=0.500$ \\
\hline \multirow[t]{6}{*}{ Soybean oil } & 0 & $10 / 10=1.000$ & $10 / 10=1.000$ & $9 / 9=1.000$ & $7 / 7=1.000$ \\
\hline & 0.1 & $10 / 10=1.000$ & $9 / 10=0.900$ & $11 / 9=1.222$ & $6 / 7=0.857$ \\
\hline & 0.2 & $16 / 10=1.600$ & $7 / 10=0.700$ & $10 / 9=1.111$ & $8 / 7=1.143$ \\
\hline & 0.5 & $12 / 10=1.200$ & $10 / 10=1.000$ & $10 / 9=1.111$ & $7 / 7=1.000$ \\
\hline & 1.0 & $8 / 10=0.800$ & $6 / 10=0.600$ & $10 / 9=1.111$ & $5 / 7=0.714$ \\
\hline & 1.5 & $8 / 10=0.800$ & $8 / 10=0.800$ & $9 / 9=1.000$ & $5 / 7=0.714$ \\
\hline \multirow[t]{6}{*}{ Cotton seed oil } & 0 & $11 / 11=1.000$ & $13 / 13=1.000$ & $11 / 11=1.000$ & $7 / 7=1.000$ \\
\hline & 0.1 & $9 / 11=0.818$ & $14 / 13=1.077$ & $10 / 11=0.909$ & $11 / 7=1.571$ \\
\hline & 0.2 & $9 / 11=0.818$ & $12 / 13=0.923$ & $8 / 11=0.727$ & $9 / 7=1.286$ \\
\hline & 0.5 & $9 / 11=0.818$ & $10 / 13=0.769$ & $7 / 11=0.636$ & $8 / 7=1.143$ \\
\hline & 1.0 & $9 / 11=0.818$ & $8 / 13=0.615$ & $9 / 11=0.818$ & $1 / 7=0.143$ \\
\hline & 1.5 & $11 / 11=1.000$ & $13 / 13=1.000$ & $10 / 11=0.909$ & $0 / 7=0.000$ \\
\hline \multirow[t]{6}{*}{ Sesame seed oil } & 0 & $7 / 7=1.000$ & $8 / 8=1.000$ & $8 / 8=1.000$ & $7 / 7=1.000$ \\
\hline & 0.1 & $8 / 7=1.143$ & $7 / 8=0.875$ & $7 / 8=0.875$ & $9 / 7=1.286$ \\
\hline & 0.2 & $8 / 7=1.143$ & $9 / 8=1.125$ & $8 / 8=1.000$ & $9 / 7=1.286$ \\
\hline & 0.5 & $9 / 7=1.286$ & $10 / 8=1.250$ & $8 / 8=1.000$ & $9 / 7=1.286$ \\
\hline & 1.0 & $10 / 7=1.429$ & $7 / 8=0.875$ & $0 / 8=0.000$ & $7 / 7=1.000$ \\
\hline & 1.5 & $11 / 7=1.571$ & $9 / 8=1.125$ & $7 / 8=0.875$ & $9 / 7=1.286$ \\
\hline \multirow[t]{6}{*}{ Macaúba almond oil } & 0 & $8 / 8=1.000$ & $10 / 10=1.000$ & $13 / 13=1.000$ & $11 / 11=1.000$ \\
\hline & 0.1 & $9 / 8=1.125$ & $11 / 10=1.100$ & $10 / 13=0.769$ & $8 / 11=0.727$ \\
\hline & 0.2 & $11 / 8=1.375$ & $15 / 10=1.500$ & $10 / 13=0.769$ & $10 / 11=0.909$ \\
\hline & 0.5 & $12 / 8=1.500$ & $11 / 10=1.100$ & $8 / 13=0.615$ & $12 / 11=1.091$ \\
\hline & 1.0 & $8 / 8=1.000$ & $10 / 10=1.000$ & $10 / 13=0.769$ & $7 / 11=0.636$ \\
\hline & 1.5 & $10 / 8=1.250$ & $8 / 10=0.800$ & $10 / 13=0.769$ & $6 / 11=0.545$ \\
\hline \multirow[t]{6}{*}{ Microalgae oil } & 0 & $8 / 8=1.000$ & $8 / 8=1.000$ & $13 / 13=1.000$ & $9 / 9=1.000$ \\
\hline & 0.1 & $12 / 8=1.500$ & $8 / 8=1.000$ & $12 / 13=0.923$ & $0 / 9=0.000$ \\
\hline & 0.2 & $11 / 8=1.375$ & $9 / 8=1.125$ & $9 / 13=0.692$ & $9 / 9=1.000$ \\
\hline & 0.5 & $9 / 8=1.125$ & $9 / 8=1.125$ & $10 / 13=0.769$ & $8 / 9=0.889$ \\
\hline & 1.0 & $9 / 8=1.125$ & $6 / 8=0.750$ & $8 / 13=0.615$ & $7 / 9=0.778$ \\
\hline & 1.5 & $8 / 8=1.000$ & $6 / 8=0.750$ & $8 / 13=0.615$ & $6 / 9=0.667$ \\
\hline
\end{tabular}

produced from spent frying oil (see Figure 4), where a marked decrease in oxidative stability was observed throughout storage, all other biodiesels proved to be more resistant to oxidation following addition with curcumin, with only slight decreases over time in their lipid oxidation induction times (see Table 3 and Figure 4). Biodiesel produced from sesame seed oil exhibited a high oxidative stability, which was kept throughout all storage timeframe. Except for the biodiesel produced from soybean oil, lipid oxidation induction times suffered large increases, from ca. $28 \%$ in the case of biodiesel produced from sesame seed oil to ca. $41 \%$ in the case of biodiesel produced from spent frying oil, when comparing the lipid oxidation induction times of biodiesels added with curcumin with their plain counterparts (see Figure 4). These results clearly demonstrate the potential of the addition of curcumin to biodiesels in maintaining (and in some cases increasing) their oxidative stability.

The results obtained for the RI of the several biodiesels throughout storage time are displayed in Figure 5.

As can be observed from inspection of Figure 5, an increase (although slight) of the RI of all biodiesels

Table 2. Lipid oxidation induction times of the several biodiesels studied, before and after addition of curcumin in the presence of water.

\begin{tabular}{|c|c|c|c|c|c|c|}
\hline \multirow[b]{2}{*}{$\begin{array}{l}\text { BIODIESEL } \\
\text { ORIGIN }\end{array}$} & \multirow[b]{2}{*}{$\begin{array}{c}\text { Density @ } 25^{\circ} \mathrm{C} \\
(\mathrm{g} / \mathrm{mL})\end{array}$} & \multirow[b]{2}{*}{$\begin{array}{c}\text { Refractive index } \\
\text { @ } 25^{\circ} \mathrm{C}\end{array}$} & \multicolumn{2}{|c|}{ Average $(n=3)$ lipid oxidation induction time $(h \pm \sigma)$} & \multirow[b]{2}{*}{$\begin{array}{l}\text { Curcumin added } \\
(\%, w / w)\end{array}$} & \multirow[b]{2}{*}{$\begin{array}{l}\text { Variation } \\
\quad(\%)\end{array}$} \\
\hline & & & $\begin{array}{c}\text { Pure } \\
\text { biodiesel }\end{array}$ & $\begin{array}{c}\text { Biodiesel added with } \\
\text { curcumin and } 1 \%(\mathrm{w} / \mathrm{w}) \text { water }\end{array}$ & & \\
\hline Spent frying oil & 0.8669 & 1.4572 & $7.12 \pm 0.02$ & $10.01 \pm 0.21$ & 0.2 & +40.59 \\
\hline Soybean oil & 0.8681 & 1.4561 & $6.01 \pm 0.20$ & $5.03 \pm 0.85$ & 0.5 & -16.31 \\
\hline Cotton seed oil & 0.8714 & 1.4531 & $3.06 \pm 0.06$ & $4.10 \pm 0.04$ & 0.1 & +33.99 \\
\hline Sesame seed oil & 0.8692 & 1.4522 & $8.70 \pm 0.12$ & $11.13 \pm 0.12$ & 0.5 & +27.93 \\
\hline Macaúba almond oil & 0.8666 & 1.4351 & $60.84 \pm 5.40$ & $141.26 \pm 2.18$ & 0.2 & +132.18 \\
\hline Microalgae oil & 0.8609 & 1.4509 & $7.58 \pm 0.07$ & $8.79 \pm 0.52$ & 0.2 & +15.96 \\
\hline
\end{tabular}




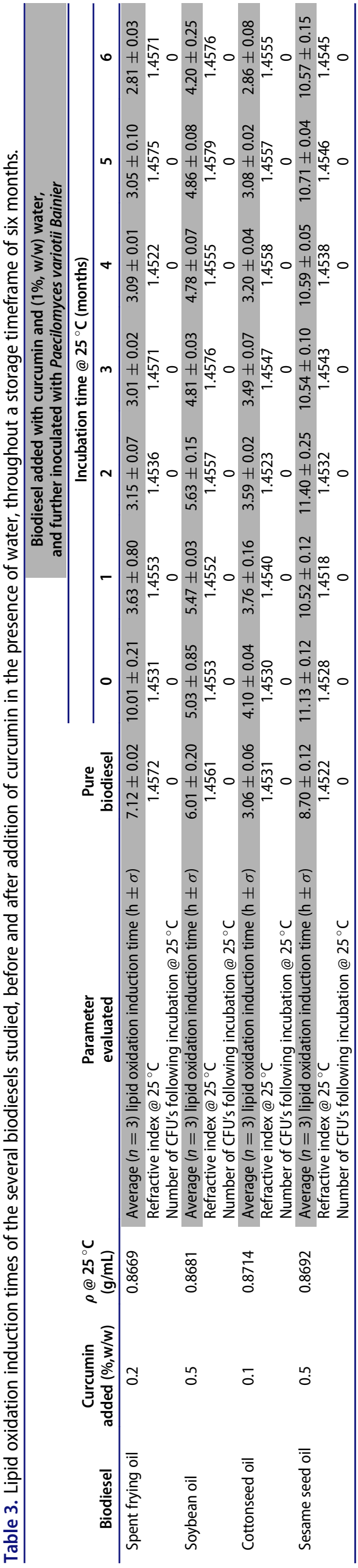

added with curcumin and $1 \%(\mathrm{w} / \mathrm{w})$ water can be noticed throughout storage time. This trend was confirmed by performing linear adjusts to the RI data of each biodiesel, producing positive slopes, viz. 0.00051430 for biodiesel produced from cottonseed oil, 0.00040356 for biodiesel produced from sesame seed oil, 0.00053572 for biodiesel produced from spent frying oil, and 0.00043215 for biodiesel produced from soybean oil (see Figure 5). The RI is a physical property that is sensitive to the effects of fatty acid oxidation, and is related to the dielectric permittivity of a material, with higher RI materials being considered highly dispersive media (such as plain vegetable oils) as compared to lower RI materials (such as biodiesels).[29,30] In general, the RI of a vegetable oil reduces tremendously after the transesterification process that leads to biodiesel, indicating that heavier molecules have been converted into lighter ones, enabling interface detection, enhancing lubricity and increasing functionality of the fuel oil.[31,32] This was actually observed in the research effort described herein, viz. the RI was reduced from 1.4743 (plain soybean oil, data not shown) to 1.4561 (biodiesel produced from soybean oil, see Table 3), from 1.4620 (plain cottonseed oil, data not shown) to 1.4531 (biodiesel produced from cottonseed oil, see Table 3), from 1.4740 (plain sesame seed oil, data not shown) to 1.4522 (biodiesel produced from sesame seed oil, see Table 3), and from 1.4800 (plain spent frying oil, data not shown) to 1.4572 (biodiesel produced from spent frying oil, see Table 3). Our results are, therefore, in clear agreement to what is described in the specialty literature. However, the slightly marginal trend of increase of the RI during storage reflects the maintenance of the physical properties of the several biodiesels, which is confirmed by the oxidative stability attained following addition of curcumin to all biofuels, in clear agreement with results published elsewhere.[3]

\section{Evaluation of the antimicrobial properties of biodiesels added with curcumin}

Biodiesels added with curcumin maintained a harsh environment that prevented microbial growth, which was confirmed by the screening of biodiesels for viable microbial cells throughout all storage timeframe, but all produced negative results (see Table 3 and Figure 6).

Addition of water to biodiesel, coupled to the prevailing carbon sources in such a medium, would allow ubiquitous microorganisms (such as Paecilomyces variotii Bainier, a common contaminating agent in diesel fuels according to Passman [5]) to thrive in them. However, addition of curcumin to biodiesel proved to be successful in fully preventing microbial growth (see Figure 6), which was confirmed by the research effort undertaken. 


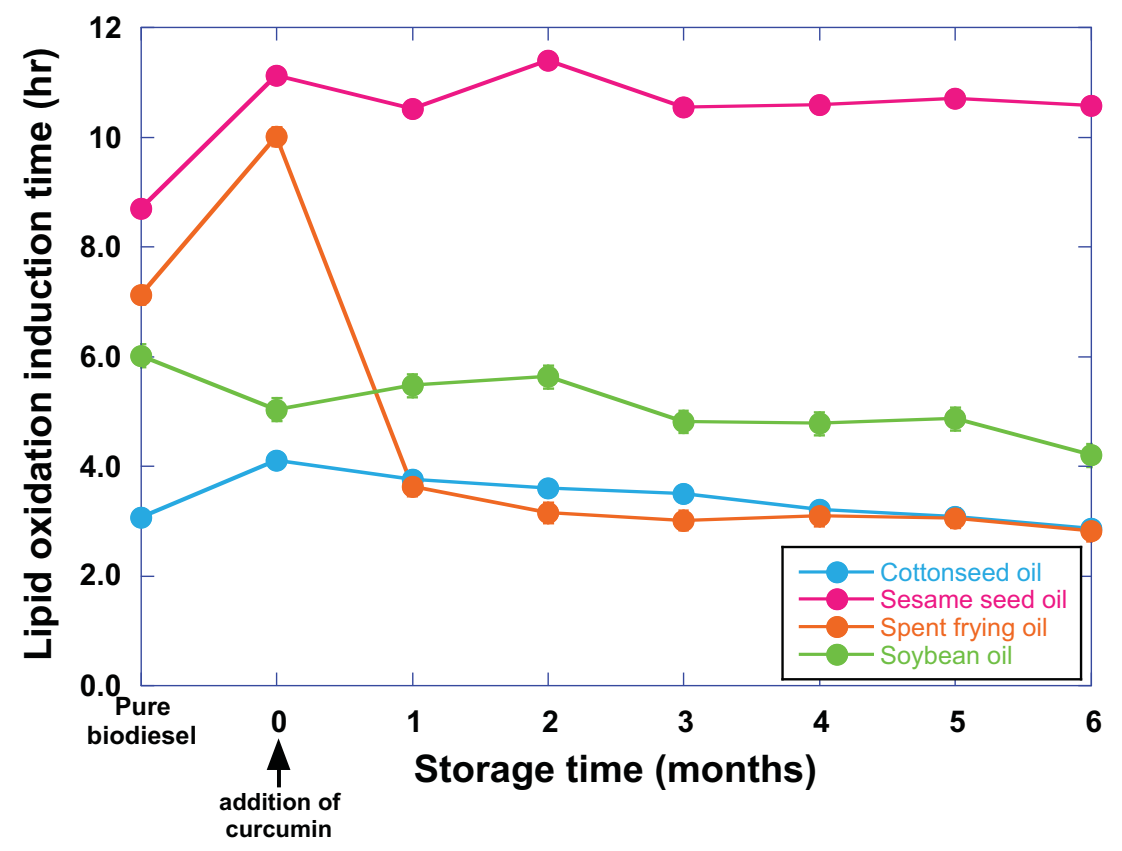

Figure 4. Oxidative stability of the several biodiesels produced, following addition with $1 \%$ water $(\mathrm{w} / \mathrm{w})$ and variable mass percentages of curcumin, and further inoculated with the ubiquitous filamentous fungi Paecilomyces variotii Bainier.

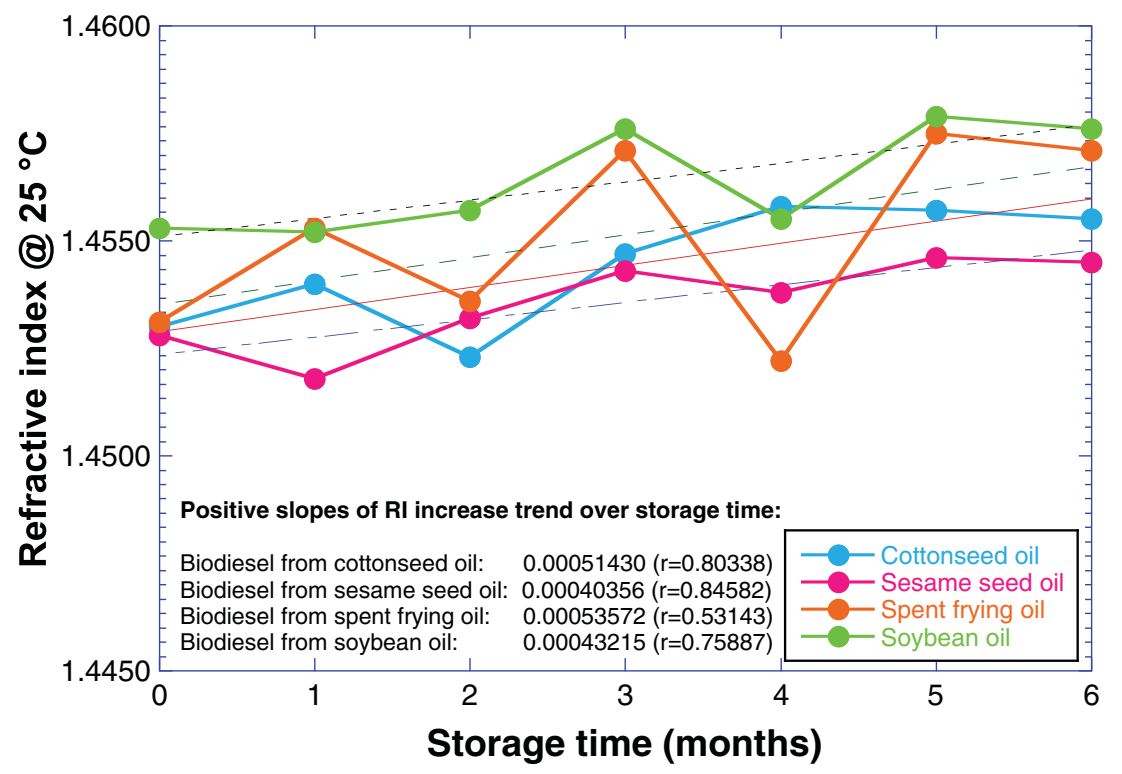

Figure 5. Evolution of the refractive index (RI) of the several biodiesels added with $1 \%$ water $(\mathrm{w} / \mathrm{w})$ and variable mass percentages of curcumin, and further inoculated with the ubiquitous filamentous fungi Paecilomyces variotii Bainier, throughout storage time.

\section{Conclusions}

An analysis of the results obtained in the research effort described herein allows us to conclude that the natural substances added to biodiesel (curcumin and pyrocatechol) presented fungistatic characteristics and were able to prevent the growth of the selected microorganism. However, from those two natural substances, curcumin was selected due not only to its ease of acquisition but also to its higher fungistatic activity. Additionally, curcumin was able to provide biodiesel with a harsh environment for contaminating fungi and to substantially increase the lipid oxidation induction times of all biodiesels tested, except for the one produced from spent frying oil which suffered a substantial decrease in its oxidative stability after only the first month of storage at room temperature. The generalized maintenance of the oxidative stability of biodiesels was supported by the observed trend in their lipid oxidation induction times. Therefore, curcumin appears as a promising antioxidant and antimicrobial natural additive for use in low mass concentrations that allows biodiesels produced from different plant sources to maintain their quality even during prolonged storage at normal ambient temperature. 


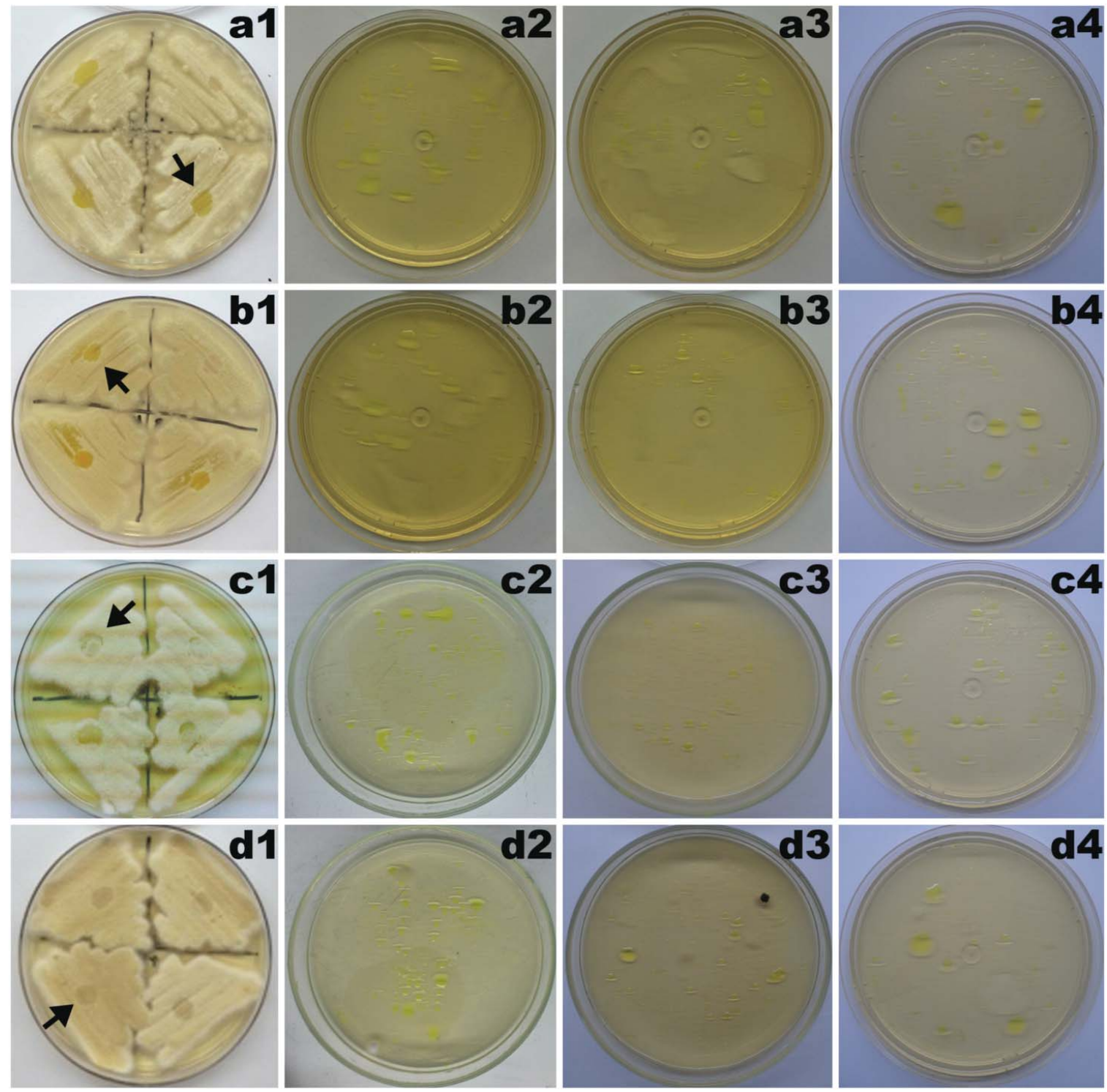

Figure 6. Demonstration of the fungistatic properties of curcumin upon addition to biodiesels produced from spent frying oil ( $\mathrm{a}_{\mathrm{i}}$ ), soybean oil $\left(\mathbf{b}_{\mathbf{i}}\right)$, cotton seed oil $\left(\mathbf{c}_{\mathbf{i}}\right)$ and sesame seed oil $\left(\mathbf{d}_{\mathbf{i}}\right)$. (Legend: a1, b1, $\mathbf{c} 1, \mathbf{d} 1$ - growth inhibition halo produced by the optimum minimum concentration of curcumin in the presence of $1 \%(\mathrm{w} / \mathrm{w})$ ultrapure water, indicated by the inserted arrow); $\mathbf{a} 2, \mathbf{b} 2$, c2, d2 - results from the screening for viable cells of the filamentous fungi in solid Sabouraud Dextrose Agar at the beginning of the storage timeframe; a3, b3, c3, d3 - results from the screening for viable cells of the filamentous fungi in solid Sabouraud Dextrose Agar at the end of the third month of storage; a4, b4, c4, d4 - results from the screening for viable cells of the filamentous fungi in solid Sabouraud Dextrose Agar at the end of the sixth month of storage.)

\section{Acknowledgments}

Project funding by CNPq (National Council for Scientific and Technological Development - Brazil) (CNPq Ref. No. 404808/ 2013-1, Project 'Studies on Biodiesel: Development of analytical methods for the characterization and quality control, and research of new natural additives to improve the quality of this biofuel'), is hereby gratefully acknowledged. This work received support from CNPq, National Council for Scientific and Technological Development - Brazil, in the form of Research Productivity (PQ) fellowships granted to Victor M. Balcão (Ref. No. 306113/2014-7) and Marco V. Chaud (Ref. No. 309598/2014-1). The authors have no conflicts of interest whatsoever to declare.

\section{Disclosure statement}

No potential conflict of interest was reported by the author.

\section{ORCID}

Victor M. Balcão (D) http://orcid.org/0000-0003-0772-2834

\section{References}

[1] Zimmer A, Cazarolli J, Teixeira RM, et al. Monitoring of efficacy of antimicrobial products during 60 days storage simulation of diesel (B0), biodiesel (B100) and blends (B7 and B10). Fuel. 2013;112:153-162.

[2] Naik SN, Goud VV, Rout PK, et al. Production of first and second generation biofuels: a comprehensive review. Renew Sust Energ Rev. 2010;14:578-597.

[3] Botella L, Bimbela F, Martín L, et al. Oxidation stability of biodiesel fuels and blends using the Rancimat and PetroOXY methods. Effectof4-allyl-2,6-dimethoxyphenol and catechol as biodiesel additives on oxidation stability. Front Chem. 2006;2(43):1-9. 
[4] Dodos GS, Konstantakos T, Longinos S, et al. Effects of microbiological contamination in the quality of biodiesel fuels. Global NEST J. 2012;14(2):175-182.

[5] Passman FJ. Microbial contamination and its control in fuels and fuel systems since 1980: a review. Int Biodeter Biodegr. 2013;81:88-104.

[6] Cazarolli JC, Bücker F, Manique MC, et al. Suscetibilidade do biodiesel de sebo bovino à biodegradação por Pseudallescheria boydii. Rev Bras Biociências. 2012;10 (3):251-257.

[7] Cazarolli JC, Guzatto R, Samios D, et al. Susceptibility of linseed, soybean, and olive biodiesel to growth of the deteriogenic fungus Pseudallescheria boydii. Int Biodeter Biodegr. 2014;95:364-372.

[8] Siegert W. Biocidal treatment and preservation of liquid fuels. In: Giles HN, editor. Proceedings of the Fifth International Conference on Stability and Handling of Liquid Fuels, Rotterdam, The Netherlands; 3-7 October 1994; Washington: U.S. Department of Energy; 1995. p. 183-194.

[9] Passman FJ. Introduction to fuel microbiology, In: Passman FJ editor. Manual 47-Fuel and Fuel System Microbiology: Fundamentals. West Conshohocken: Diagnosis and Contamination Control, ASTM International; 2003. p. 1-13.

[10] Bücker F, Santestevan NA, Roesch LF, et al. Impact of biodiesel on biodeterioration of stored Brazilian diesel oil. Int Biodeter Biodegr. 2011;65:172-178.

[11] Raikos V, Vamvakas SS, Sevastos D, et al. Water content, temperature and biocide effects on the growth kinetics of bacteria isolated from JP-8 aviation fuel storage tanks. Fuel. 2012;93:559-566.

[12] Cavalcanti EHS. Estabilidade do Biodiesel e Misturas Abrangência, Limitações dos Métodos de Avaliação e Alternativas Futuras [Stability of biodiesel and mixtures Scope, Limitations of Evaluation Methods and Future Alternatives]. Rev Biodiesel. 2009;3:71-73.

[13] Castro AG. Study of curcumin influence in the Oxidative Stability of Biodiesel and Vegetable Oil [Estudo da Influência da Curcumina na Estabilidade Oxidativa de Biodieseis e Óleos Vegetais]. Ph.D. Thesis. Campinas SP, Brazil: Institute of Chemistry of the State University of Campinas; 2013.

[14] Serrano M, Bouaid A, Martinez M, et al. Oxidation stability of biodiesel from different feedstocks: influence of commercial additives and purification step. Fuel. 2013;113:50-58.

[15] Shaikh J, Ankola DD, Beniwal V, et al. Nanoparticle encapsulation improves oral bioavability of curcumin by at least 9-fold when compared to curcumin administered with piperine as absorption enhancer. Eur J Pharm Sci. 2009;37:223-230.

[16] Akram M, Uddin S, Ahmed A, et al. Curcuma longa and curcumin: a review article. Rom J Biol - Plant Biol. 2010;55(2):65-70.

[17] Shrishail D, Harishk $H$, Ravichandra $H$, et al. Turmeric: nature's precious medicine. Asian J Pharm Clin Res. 2013;6(3):10-16.
[18] Kocacaliskana I, Talanb I, Terzic I. Antimicrobial activity of catechol and pyrogallol as allelochemicals. Z Naturforsch. 2006;61:639-642.

[19] Schweigert N, Zehnder AJB, Eggen EIL. Chemical properties of catechols and their molecular modes of toxic action in cells, from microorganisms to mammals. Env Microbiol. 2001;3(2):81-91.

[20] Basile A, Ferrara L, del Pezzo M, et al. Antibacterial and antioxidant activities of ethanol extract from Paullinia cupana Mart. J Ethnopharm. 2005;102:32-36.

[21] Perron, NR, Brumaghim, JL. A Review of the antioxidant mechanisms of polyphenol compounds related to iron binding. Cell Biochem Biophys. 2009;53:75-100.

[22] Coawn, MM Plant products as antimicrobial agents. Clin Microbiol Rev. 1999;12(4):564-582.

[23] CLSI. Performance Standards for Antimicrobial Susceptibility Testing: Twenty-First Informational Supplement. CLSI document M100-S21. Wayne, PA: Clinical and Laboratory Standards Institute; 2011.

[24] European Committee for Standardization. EN 14112: 2003 - Fat and Oil Derivatives - Fatty Acid Methyl Esters (FAME). Determination of oxidation stability (accelerated oxidation test). Belgium: European Committee for Standards (CEN); 2003.

[25] Borsato D, Cini JRM, Silva HC, et al. Oxidation kinetics of biodiesel from soybean mixed with synthetic antioxidants BHA, BHT and TBHQ: determination of activation energy. Fuel Process Technol. 2014;127:111-116.

[26] ANP - Agência Nacional do Petróleo [Brazilian National Petroleum Agency]. ANP Resolution 42/2004. 2004; Available at: www.anp.gov.br/petro/legis_qualidade.asp.

[27] NCCLS. Methods for dilution antimicrobial susceptibility tests for bacteria that grow aerobically, approved standard, Seventh Edition. Wayne, PA: NCCLS Approved Standard M7-A7 26 (2) Clinical and Laboratory Standards Institute; 2006.

[28] ASTM. ASTM E1259-10, Standard Practice for Evaluation of Antimicrobials in Liquid Fuels Boiling Below $390^{\circ} \mathrm{C}$, West Conshohocken, PA: ASTM International; 2010, www.astm.org.

[29] Sadrolhosseini AR, Moksin MM, Nang HLL, et al. Physical properties of normal grade biodiesel and winter grade biodiesel. Int J Mol Sci. 2011;11:2100-2111 (doi:10.3390/ijms12042100).

[30] Wazilewski WT, Bariccatti RA, Martins Gl, et al. Study of the methyl crambe (Crambe abyssinica Hochst) and soybean biodiesel oxidative stability. Ind Crop Prod. 2013;43:207-212.

[31] Raja AS, Smart RDS, Lee LCR. Biodiesel production from jatropha oil and its characterization. Res J Chem Sci. 2011;1(1):81-87.

[32] Aliyu AO, Nwaedozie JM, Adams A. Quality Parameters of Biodiesel Produced from Locally Sourced Moringa oleifera and Citrullus colocynthis L. Seeds Found in Kaduna, Nigeria. Int Res J Pure Ap Chem. 2013;3(4):377-390. 